\title{
Orgaanisten lannoitevalmisteiden hallittu varastointi peltopattereissa
}

\author{
Tiina Tontti ${ }^{1)}$, Petri Kapuinen ${ }^{2)}$, Marika Laurila ${ }^{3)}$ ja Jarkko Kekkonen ${ }^{3)}$ \\ 1) Maa- ja elintarviketalouden tutkimuskeskus MTT, Kasvintuotannon tutkimus, Lönnrotinkatu 3, \\ 50100 Mikkeli, tiina.tontti@mtt.fi \\ ${ }^{2)}$ Maa- ja elintarviketalouden tutkimuskeskus MTT, Kasvintuotannon tutkimus, Toivonlinnantie 518, \\ 21500 Piikkiö, petri.kapuinen@mtt.fi \\ ${ }^{3)}$ Maa- ja elintarviketalouden tutkimuskeskus MTT, Kotieläintuotannon tutkimus, Tutkimusasemantie \\ 15,92400Ruukki, marika.laurila@mtt.fi,jarkko.kekkonen@mtt.fi
}

\section{Tiivistelmä}

Maanparannuskompostin, kuivatun mädätysjäännöksen ja kemiallisesti hapetetun puhdistamolietteen varastointia peltopattereissa on seurattu eri puolilla Suomea. Patterit perustettiin talvella routaantuneen maan päälle, ja niiden alla oli paljas maa, turve, sahanpuru tai olki. Pattereiden koko vastasi kyseisellä peltolohkolla käytettävää määrää. Pattereiden kohdalta ja ympäröivästä peltomaasta mitattiin typpipitoisuudet eri maakerroksista ennen ja jälkeen varastoinnin.

Ensimmäiset tulokset (Pohjois-Pohjanmaa, HHt, m) kemiallisesti hapetetun puhdistamolietteen turve-, olki- ja paljaspohjaisen pattereiden liukoisen typen huuhtoutumisesta viittaavat siihen, että vaikutus rajoittuu peltopatterin kohtaan ja siinäkin vain ylimpiin maakerroksiin. Keväällä patterin purkamisen aikaan huuhtoutunut liukoinen typpi oli ammoniummuodossa $\left(\mathrm{NH}_{4}{ }^{+}-\mathrm{N}\right)$, nitraattityppeä ei havaittu. Typen huuhtoutumista varastopattereista pintavalunnan mukana valumasuuntaan ei havaittu.

Pohjois-Pohjanmaalla yhden patterin koko oli noin $120 \mathrm{~m}^{3}$ ja patterin alla oleva pinta-ala oli noin $110 \mathrm{~m}^{2}$. Pohjamateriaalia levitettiin lumesta auratulle routaantuneelle pellolle $5-10 \mathrm{~cm}$, lietetuotetta tuotiin kuhunkin patteriin noin $40 \mathrm{t}$, ja peitettiin oljella. Tulosten perusteella turvepohjaisen patterin alla maassa oli keväällä patteria purettaessa suuremmat $\mathrm{NH}_{4}{ }^{+}-\mathrm{N}$-pitoisuudet kuin olki- tai paljaspohjaisen patterin alla. Ylimmässä $10 \mathrm{~cm}$ maakerroksessa $\mathrm{NH}_{4}{ }^{+}-\mathrm{N}$-pitoisuus oli turvepohjaisella $920 \mathrm{mg} / \mathrm{l}$, olkipohjaisella $180 \mathrm{mg} / \mathrm{l}$ ja paljaspohjaisella patterilla $420 \mathrm{mg} / \mathrm{l}$. Pohjakerroksen nesteensitomiskyky saattoi olla liian pieni suhteessa lietetuotteen alimmista kerroksista puristuvaan nestemäärään.

Vaikka patterin alla olevista maakerroksista mitatut typpipitoisuudet ovat suuret, on maahan siirtyneen typen kuormitus maanparannusaineen käyttölohkon peltohehtaaria kohden laskettuna pieni. Näistä samalla peltolohkolla olleista pattereista $\mathrm{NH}_{4}{ }^{+}-\mathrm{N}$ siirtymä patterin alla olleisiin maakerroksiin oli paljaspohjaisessa 7,7 kg, olkipohjaisessa 4,8 kg ja turvepohjaisessa 15,9 kg. Kun yhden patterin levitysala oli noin 5 ha, tuli eri patterirakenteilla typpikuormituksen määräksi tuotteen käyttöalaa kohti pienimmillään $0,96 \mathrm{~kg} \mathrm{~N} / \mathrm{ha}$ (olkipohjainen) ja suurimmillaan $3,18 \mathrm{~kg} \mathrm{~N} / \mathrm{ha}$ (turvepohjainen). Muilla seurantakohteilla keväällä mitattu liukoisen typen pitoisuus patterin alla oli näitä lukemia pienempi.

Patterien aiheuttamaa pistekuormaa peltolohkolla voi hallita oikeilla pohjarakenteilla ja varastopaikan viimeistelyllä. Voidaan käyttää nestettä sitovaa mutta myös kantavaa pohjamateriaalia ja tarvittaessa suorittaa lohkolla massanvaihtoa noin $20 \mathrm{~cm}$ syvyydeltä patterin kohdalla. Varastopatteria ei tule sijoittaa salaojan kohdalle. Orgaanisten lannoitevalmisteiden peltopatteroinnista aiheutuva ympäristönkuormitus on vähäinen. Sallimalla orgaanisten lannoitevalmisteiden peltopatterointi voitaisiin niiden sisältämät ravinteet hyödyntää kasvintuotannossa ja samalla edistää ravinteiden kierrätystä.

\section{Asiasanat:}

maanparannuskomposti, mädätysjäännös, puhdistamoliete, varastointi, patteri, ammoniumtyppi, nitraattityppi 


\section{Johdanto}

Orgaanisia lannoitevalmisteita tuotetaan yhdyskuntaperäisistä raaka-aineista, puhdistamolietteestä ja erilliskerätystä biojätteestä, keskitetyissä laitoksissa ympäri maata ja niitä markkinoidaan myös viljelijöille peltokäyttöön. Orgaanisten lannoitevalmisteiden varastointi saattaa tuntua viljelijästä hankalalta ja niiden oikeista ja sallituista varastointitavoista on epäselvyyttä, koska valmisteet usein poikkeavat karjanlannoista mutta erityisesti mineraalilannoitteista. Toisaalta myös ympäristöviranomaisten käsitys ja tulkinnat orgaanisten lannoitevalmisteiden varastointivaatimuksista on voinut olla hatara ja vaihdella paikkakuntakohtaisesti, koska tällaisten tuotteiden peltovarastoinnin vaikutuksista ei ole ollut käytännöllistä tietoa.

Hankkeen tavoitteena on selvittää orgaanisten lannoitevalmisteiden peltovarastoinnin eli patteroinnin aiheuttama potentiaalinen ympäristökuormitus mittaamalla peltomaan ammonium- ja nitraattitypen pitoisuuden muutos käytännön tilakohteiden peltopattereiden alla ja ympäristössä varastoinnin kuluessa varastoitaessa valittuja esimerkkituotteita. Esimerkkituotteita ovat kemiallisesti hapetettu lietetuote, maanparannuskomposti ja kuivattu mädätysjäännös, joissa kaikissa on raakaaineena puhdistamolietettä.

\section{Aineisto ja menetelmät}

Viljelijät perustivat vuosien 2012 ja 2013 alussa (tammi-helmikuu) pelloilleen varastopattereita ympäristöviranomaisten hyväksymien pohjaratkaisujen mukaisesti Loviisassa, Kouvolassa ja Limingassa. Peltolohkolla käytettävää tuotemäärää vastaavat patterit perustettiin talvella routaantuneen ja lumesta auratun maan päälle. Pattereiden alla oli paljas maa tai sille levitettiin turvetta tai olkea. Patterit peitettiin käytännössä ainoastaan Limingassa (olkikate, n. 10-20 cm). Pattereiden kohdalta ja ympäröivästä peltomaasta mitattiin typpipitoisuudet eri maakerroksista (0-10 $\mathrm{cm}, 10-20 \mathrm{~cm}, 20-30 \mathrm{~cm}, 30-40 \mathrm{~cm}, 40-50 \mathrm{~cm}$ ja $50-60 \mathrm{~cm}$ ) ennen varastointia (loppusyksy tai talvi) ja heti varastoinnin jälkeen toukokuussa patterin purkupäivänä.

Varastopatterin vaikutusta maan ammoniumtypen ja nitraattitypen pitoisuuksiin mitattiin patterin alla ja sen potentiaalisessa valumasuunnassa määrävälein kerroksittain. Patterin alta tehdyn mittauksen tavoitteena oli selvittää alaspäin suuntautuva liukoisen typen huuhtoutuminen. Potentiaalisessa valumasuunnassa tehtävän mittauksen tavoitteena oli selvittää mahdolliset liukoisen typen huuhtoutumiset patterista sen ympäristöön. Kerroksittaiset maanäytteet peltopatterina alla otettiin 4-6 kohdasta sen alta edustavasti ja patterista lähtien $3 \mathrm{~m}, 10 \mathrm{~m}$ ja $30 \mathrm{~m}$ etäisyyksiltä (2 rinnakkaista kairausta kustakin) peltolohkon arvioidun veden valumasuunnan mukaisesti.

Kerroksittaiset maanäytteet otettiin $60 \mathrm{~cm}$ syvyyteen saakka $10 \mathrm{~cm}$ :n välein ja yhdistettiin kerroksittain samaan näytepussiin, jotta maakerroksen näytemäärä tuli riittävän suureksi kemiallisiin analyyseihin. Maanäytekairana käytettiin joko ns. typpikairaa tai lusikkakairaa, peltomaan ominaisuuksien perusteella. Maanäytteet jäähdytettiin heti näytteenoton jälkeen kylmälaukuissa ja kuljetettiin saman päivän aikana pakastimeen. Näytteet vietiin pakastettuina kaupalliseen laboratorioon ja siellä sulatetuista näytteistä analysoitiin $\mathrm{NH}_{4}^{+}$- ja $\mathrm{NO}_{3}^{-}$-typpi $\left(0,1 \mathrm{M} \mathrm{K}_{2} \mathrm{SO}_{4}\right.$, uuttosuhde 1:2,5 w/w) vesikemian menetelmillä. Typpiprofiilien tulokset esitetään yksittäisten tulosten pohjalta. Tässä tilakohteilta kerätyssä seuranta-aineistossa ei ole toistoja, mutta peräkkäisinä vuosina samoilla ratkaisuilla toteutetut patterit voivat vahvistaa tulosten luotettavuutta.

Lannoitevalmisteesta puristuvan valumaveden määrää mitattiin pilot-tyyppisellä patterisimulaattorilla MTT:ssä. Kuivattua mädätysjäännöstä $(31,5 \% \mathrm{DM})$ varastoitiin $1,7 \mathrm{~m}^{3}$ kokoiseen (pinta-ala $1 \mathrm{~m}^{2}$ ) laatikkoon ja tuotteesta valuva neste kerättiin talteen. Sulasta mädätysjäännösmassasta valuvan veden määrä mitattiin noin 65 vuorokauden ajan (lämpötila $<+15$ $\left.{ }^{\circ} \mathrm{C}\right)$. Valumavedestä analysoitiin lannoitevalmisteanalyysien mukaisesti liukoinen typpi sekä $\mathrm{NH}_{4}{ }^{+}-\mathrm{ja}$ $\mathrm{NO}_{3}{ }^{-}$-typpi. 


\section{Tulokset ja tulosten tarkastelu}

\section{Typpiprofiilit eri lannoitevalmisteiden alla ilman pohjakerrosta}

Paljaspohjaisten lannoitevalmistepatterien purkamisen aikaan peltomaan ammoniumtyppipitoisuudessa oli selvä vertikaalinen profiili (Taulukko 1.). Ammoniumtypen pitoisuus oli kohonnut maan pintakerroksissa, lähinnä 0-10 $\mathrm{cm}$ ja $10-20 \mathrm{~cm}$ sekä joissakin tapauksissa myös 20-30 cm makerroksessa. Ammoniumtypen profiilit olivat samankaltaiset kaikkien paljaspohjaisten patterien kohdalla, lukuun ottamatta kemiallisesti hapetetun puhdistamolietteen paljaspohjaista patteria vuonna 2013. Nitraattityppeä patterin alla olleissa maakerroksissa oli hyvin vähän. Eräs syy paljaspohjaisen patterin poikkeavaan ammoniumprofiiliin vuonna 2013 saattaisi olla suuren sadannan aiheuttama huuhtoutuminen alaspäin. Sadevesien ja patterin peittämisen vaikutusta huuhtoutumiseen ei tämän aineiston pohjalta pysty arvioimaan.

Orgaanisissa lannoitevalmistetuotteissa ei yleensä ole nitraattia, vaan tuotteiden liukoinen typpi on pääosin ammoniummuodossa. Nitraattia on vain hyvin kompostoituneissa orgaanisissa lannoitevalmisteissa, kuten maanparannuskompostissa. Kun lannoitevalmistepatteri puretaan kevättöiden aikaan, heti kun pelto on kylvökunnossa, on varastopatterin alapuolella oleva maa viileää. Tällöin maan pintakerroksissa oleva liukoinen typpi on ammoniummuodossa. Nitrifikaatiota eli ammoniumtypen muuntumista nitraatiksi tapahtuu myöhemmin purkamisajan jälkeen kasvukauden aikana ja kun maa on lämmennyt.

Taulukko 1. Maakerrosten $\mathrm{NH}_{4}{ }^{+}$- ja $\mathrm{NO}_{3}^{-}$-typen profiilit maanparannuskompostin, kuivatun mädätysjäännöksen ja kemiallisesti hapetetun puhdistamolietteen varastopatterien alla, sekä 3 metrin ja 10 metrin etäisyyksillä pattereista. Näytteet on otettu toukokuussa varastopatterien purkamispäivänä, patterin ulkopuoliset pisteet ennen lannoitevalmisteen levitystä ja patterin kohta heti purkamisen jälkeen.

\section{PALJASPOHJAISET LANNOITEVALMISTEPATTERIT ${ }^{(1)}$}

Maakerrosten $\mathrm{NH}_{4}{ }^{+} \mathrm{ja} \mathrm{NO}_{3}{ }^{-}$-typpi patterin purkamis essa toukokuussa

\begin{tabular}{|c|c|c|c|c|c|c|c|c|c|c|c|c|}
\hline & \multicolumn{4}{|c|}{ Maanparannusk omposti } & \multicolumn{4}{|c|}{ Mädätysjäännös kuivattu } & \multicolumn{4}{|c|}{ Kemiallisesti hapetettu puhdistamoliete } \\
\hline & \multicolumn{2}{|c|}{$\begin{array}{c}2012(\mathrm{HeS}) \\
\text { (mg/litra) }\end{array}$} & \multicolumn{2}{|c|}{$\begin{array}{c}2013(\mathrm{HeS}) \\
(\mathrm{mg} / \mathrm{kg})\end{array}$} & \multicolumn{2}{|c|}{$\begin{array}{c}2012 \text { (HsS) } \\
\text { (mg/litra) }\end{array}$} & \multicolumn{2}{|c|}{$\begin{array}{c}2013 \text { (HsS) } \\
(\mathrm{mg} / \mathrm{kg})\end{array}$} & \multicolumn{2}{|c|}{$\begin{array}{c}2012 \text { (HHt) } \\
\text { (mg/litra) }\end{array}$} & \multicolumn{2}{|c|}{$\begin{array}{c}2013 \text { (HHt) } \\
(\mathrm{mg} / \mathrm{kg})\end{array}$} \\
\hline & $\mathrm{NH}_{4}^{+}-\mathrm{N}$ & $\mathrm{NO}_{3}{ }^{-}-\mathrm{N}$ & $\mathrm{NH}_{4}^{+}-\mathrm{N}$ & $\mathrm{NO}_{3}{ }^{-}-\mathrm{N}$ & $\mathrm{NH}_{4}^{+}-\mathrm{N}$ & $\mathrm{NO}_{3}{ }^{-}-\mathrm{N}$ & $\mathrm{NH}_{4}^{+}-\mathrm{N}$ & $\mathrm{NO}_{3}{ }^{-}-\mathrm{N}$ & $\mathrm{NH}_{4}^{+}-\mathrm{N}$ & $\mathrm{NO}_{3}^{-}-\mathrm{N}$ & $\mathrm{NH}_{4}{ }^{+}-\mathrm{N}$ & $\mathrm{NO}_{3}^{-}-\mathrm{N}$ \\
\hline \multicolumn{13}{|l|}{ Patterin kohdalla } \\
\hline kerrokset $\quad 0-10$ & 216 & 11 & 139 & 2 & 125 & 32 & 317 & 1 & 430 & 0 & 75 & 3 \\
\hline * $10-20$ & 106 & 7 & 8 & 2 & 66 & 16 & 49 & 1 & 120 & 0 & 93 & 2 \\
\hline $20-30$ & 153 & 5 & 3 & 1 & 28 & 7 & 1 & 1 & 96 & 0 & 138 & 2 \\
\hline $30-40$ & 6 & 4 & 1 & 2 & 11 & 4 & 0 & 1 & 21 & 0 & 128 & 2 \\
\hline $40-50$ & 3 & 4 & 2 & 1 & 1 & 4 & 2 & 1 & 4 & 0 & 130 & 2 \\
\hline $50-60$ & 2 & 2 & 2 & 2 & 1 & 3 & 1 & 1 & 7 & 0 & 59 & 3 \\
\hline \multicolumn{13}{|c|}{ Patterista 3 m etäisyys } \\
\hline kerrokset $\quad 0-10$ & 231 & 20 & 150 & 14 & 3 & 2 & 3 & 24 & 39 & 2 & 14 & 2 \\
\hline $10-20$ & 49 & 8 & 4 & 2 & 2 & 2 & 3 & 7 & 5 & 0 & 9 & 1 \\
\hline $20-30$ & 4 & 7 & 2 & 2 & 2 & 1 & 5 & 3 & 3 & 0 & 7 & 2 \\
\hline $30-40$ & 8 & 7 & 5 & 1 & 2 & 1 & 0 & 3 & 4 & 0 & 16 & 3 \\
\hline $40-50$ & 1 & 4 & 7 & 2 & 1 & 1 & 1 & 2 & 0 & 0 & 3 & 2 \\
\hline $50-60$ & 4 & 3 & 32 & 3 & 0 & 1 & 1 & 1 & 0 & 0 & - & - \\
\hline \multicolumn{13}{|c|}{ Patterista 10 m etäisyys } \\
\hline kerrokset $\quad 0-10$ & 36 & 16 & & & 2 & 3 & & & 3 & 0 & 5 & 1 \\
\hline $10-20$ & 4 & 7 & & & 1 & 2 & & & 5 & 2 & 8 & 3 \\
\hline $20-30$ & 14 & 8 & & & 1 & 1 & & & 7 & 2 & 3 & 2 \\
\hline $30-40$ & 1 & 4 & & & 1 & 1 & & & 4 & 0 & 1 & 1 \\
\hline $40-50$ & 0 & 3 & & & 0 & 1 & & & 5 & 2 & 1 & 2 \\
\hline $50-60$ & 1 & 3 & & & 0 & 1 & & & 6 & 0 & - & - \\
\hline
\end{tabular}

(1) Perustettu talvella jäiselle maalle 
Kohonneet ammoniumtyppipitoisuudet rajoittuivat varsin selkeästi patterin kohdalle. Ammonium- ja nitraattitypen kulkeutumista pintavalunnan mukana ei yleensä havaittu. Joissakin seurantakohteissa patterien perustamisessa tapahtunut kuormausajo valumalinjan suunnasta ja tuotteen leviäminen patterin lähistölle saattoi vaikuttaa $\mathrm{N}$-tasojen hienoiseen nousuun. Patterista huuhtoutuu liukoista typpeä käytännössä vain alaspäin.

Maanparannuskomposti ja kuivattu mädätysjäännös varastoitiin savimaalla ja lähes kokonaan ilman pohjamateriaalia. Vuonna 2012 mädätysjäännöksen alle oli laitettu hyvin pieni määrä olkisilppua, mutta sitä ei ollut havaittavissa enää purkamisen yhteydessä. Kemiallisesti hapetetun puhdistamolietteen alla maakerrosten ( $\mathrm{HHt}$ ) ammoniumtypen profiili oli vuonna 2012 samankaltainen kuin maanparannuskompostin ja mädätysjäännöksen alla. Vuonna 2013 kemiallisesti hapetetun puhdistamolietteen varastopatterin alla maakerrosten ammoniumtyppipitoisuus oli muista poikkeava. Syvyyksillä 20-50 cm oli ammoniumtyppeä enemmän kuin ylemmissä pintakerroksissa, noin 130 $\mathrm{mg} / \mathrm{kg}$. Nitraattitypen pitoisuudet maakerroksissa olivat tällöinkin alhaisia, alle $5 \mathrm{mg} / \mathrm{kg}$.

Karkea kivennäismaalaji todennäköisesti nopeuttaa typen kulkeutumista maakerroksissa savimaahan verrattuna. Karkeilla kivennäismaalla patterin pohja onkin syytä tehdä erityisen huolellisesti ja varastopaikka on viimeisteltävä tarkasti purkamisen jälkeen. Maalajin lisäksi myös peltomaan muilla olosuhteilla on vaikutusta. Lannoitevalmisteen kosteus vaikuttaa myös selkeästi tuotteen aiheuttamaan valumaan. Mitä kuivempaa lannoitevalmiste on, sitä vähemmän siitä puristuu nestettä oman painon alla varastoinnin aikana.

Patterin alla olleissa maakerroksissa ammoniumtypen määrät olivat kohonneet, mutta vaikutus oli pistemäinen. Pistemäisen vaikutuksen vuoksi onkin hämäävää laskea typpimäärät hehtaaria kohti, joten paremmin todellista patterin vaikutusta kuvaa typpimäärän kerrossumma yksiköllä " $\mathrm{kg} / \mathrm{m}^{2}$ " (Taulukko 2). Taulukossa 2 on laskettu erityyppisten lannoitevalmisteiden varastopatterien alla olleiden maakerrosten typpimäärät yhteen eri pinta-aloja kohti. Patterin koon mukaan on laskettu typpipäästö patteria kohti ja jaettu tämä patterin pistemäinen vaikutus patterin levitysalaa kohti. Maanparannuskompostin alla maakerroksiin siirtynyt typpi $\left(\mathrm{NH}_{4}{ }^{+}\right.$ja $\left.\mathrm{NO}_{3}^{-}\right)$oli peltolohkon alalle jaettuna ensimmäisenä vuonna $0,63 \mathrm{~kg} \mathrm{~N} / \mathrm{ha}$ ja toisena vuonna $0,16 \mathrm{~kg} \mathrm{~N} / \mathrm{ha}$. Vastaavasti mädätysjäännöksen alla mitattu typpimäärä lohkon pinta-alalle oli ensimmäisenä vuonna $0,59 \mathrm{~kg} \mathrm{~N} / \mathrm{ha}$ ja toisena vuonna $1,57 \mathrm{~kg} \mathrm{~N} / \mathrm{ha}$. Kemiallisesti hapetetun lietteen alla mitattu typpimäärä oli lohkon pinta-alalle jaettuna $1,51 \mathrm{~kg} \mathrm{~N} / \mathrm{ha} \mathrm{ja} 1,86 \mathrm{~kg} \mathrm{~N} / \mathrm{ha}$.

Taulukko 2. Paljaspohjaisten varastopatterien kohdalta mitattu $\mathrm{NH}_{4}{ }^{+}-$ja $\mathrm{NO}_{3}{ }^{-}$-typen pistemäinen kuormitus lannoitevalmisteen levitysalaa kohti laskettuna.

\begin{tabular}{|c|c|c|c|c|c|c|}
\hline & \multicolumn{2}{|c|}{$\begin{array}{l}\text { Maanparannus kompostin paikka } \\
\text { Paljaspohjainen patteri (HeS) }\end{array}$} & \multicolumn{2}{|c|}{\begin{tabular}{|l|} 
Mädätysjäännöksen paikka \\
Paljaspohjainen patteri (HsS)
\end{tabular}} & \multicolumn{2}{|c|}{\begin{tabular}{|l|} 
Kem.hapetetun lietteen paikka \\
Paljaspohjainen patteri (HHt)
\end{tabular}} \\
\hline & $\begin{array}{c}2012 \\
\mathrm{NH}_{4}^{+}+\mathrm{NO}_{3}^{-} \\
\end{array}$ & $\begin{array}{l}\mathbf{2 0 1 3}^{(1)} \\
\mathrm{NH}_{4}^{+}+\mathrm{NO}_{3}^{-}\end{array}$ & $\begin{array}{l}\mathbf{2 0 1 2}^{(2)} \\
\mathrm{NH}_{4}^{+}+\mathrm{NO}_{3}^{-}\end{array}$ & $\begin{array}{l}\mathbf{2 0 1 3}^{(1)} \\
\mathrm{NH}_{4}^{+}+\mathrm{NO}_{3}^{-}\end{array}$ & \begin{tabular}{|}
2012 \\
$\mathrm{NH}_{4}{ }^{+}+\mathrm{NO}_{3}^{-}$ \\
\end{tabular} & $\begin{array}{l}2^{2013}{ }^{(1)} \\
\mathrm{NH}_{4}{ }^{+}+\mathrm{NO}_{3}{ }^{-}\end{array}$ \\
\hline Kerrossumma $^{(3)}(\mathrm{kg} / \mathrm{ha})$ & 522 & 165 & 292 & 375 & 678 & 637 \\
\hline Kerrossumma neliölle (kg/m²) & 0.052 & 0.017 & 0.029 & 0.037 & 0.068 & 0.064 \\
\hline Patterin ala $\left(\mathrm{m}^{2}\right) /$ Lohkon ala (ha) & $300 / 25$ & $105 / 10,8$ & $50 / 2,48$ & $392 / 9,36$ & $114 / 5,13$ & $150 / 5,13$ \\
\hline$N$-päästö (kg/patteri) & 15.7 & 1.7 & 1.5 & 14.7 & 7.7 & 9.6 \\
\hline Liukoinen N levitysalaa kohti (kg N/ha) & 0.63 & 0.16 & 0.59 & 1.57 & 1.51 & 1.86 \\
\hline
\end{tabular}

\section{Pohjamateriaalit varastopatterien alla}

Pohjois-Pohjanmaalla varastoitiin kemiallisesti hapetettua lietettä samalla lohkolla $(\mathrm{HHt}, \mathrm{m})$ kolmella pohjaratkaisulla ja kahtena peräkkäisenä vuotena (eri sijainnit lohkolla). Eri pohjaratkaisujen välillä maakerrosten $\mathrm{NH}_{4}{ }^{+}$-pitoisuuden profiilit olivat keskenään samanlaiset (Taulukko 3). Ainoastaan paljaspohjaisen patterin alla vuonna 2013 havaittiin poikkeava $\mathrm{NH}_{4}{ }^{+}$-typen profiili (esitetty jo 
taulukossa 1). Maakerrosten $\mathrm{NO}_{3}{ }^{-}$-typen pitoisuudet olivat kaikkien patterien kohdalla ja kaikissa kerroksissa alle $5 \mathrm{mg} / \mathrm{kg}$.

Pohjakerroksella voi olla selkeää hyötyä lannoitevalmisteesta puristuvan nesteen sitomisessa. Karkeilla kivennäismaalla mitatut kemiallisesti hapetetun lietteen patterien tulokset eivät kuitenkaan olleet yksiselitteisiä. Tuloksissa on yksi tulossarja pohjamateriaalia kohti vuosittain, toistoja ei tässä tilakohteilta kerätyssä seuranta-aineistossa vuoden sisällä ole. Kemiallisesti hapetetun lietteen varastopattereista on kuitenkin samanlaisten pohjaratkaisujen tulokset kahdelta peräkkäiseltä vuodelta ja samalta peltolohkolta.

Turvepohja ja olkipohja vaikuttavat toimivilta, sillä ammoniumtyppeä oli eniten ylimmissä maakerroksissa. Todennäköisesti turve-/olkikerros hidastaa pystysuoraa nestevalumaa patterin alla, mutta kerrospaksuuden on oltava riittävän suuri. Patterin pohjamateriaalin nesteensitomiskyvyn tulee myös olla hyvä. Paljaspohjaisen patterin $\mathrm{NH}_{4}{ }^{+}-\mathrm{N}$-profiili oli ensimmäisenä vuonna yllättäen samankaltainen kuin turpeen ja oljen tapauksessa, kun taas toisena vuonna paljaspohjaisen vaikutus oli muista poikkeava. Toisaalta ensimmäisenä vuonna turvepohjan alta ylimmistä kerroksista mitatut $\mathrm{NH}_{4}{ }^{+}$-N-pitoisuudet olivat yllättävän suuret. Poikkeamia voivat selittää mahdolliset erot puhdistamolietteen ravinnepitoisuuksissa, pohjaeristeen sekoittuminen patterien purun yhteydessä pintamaahan tai näytteenotossa tapahtuneet poikkeamat. Pohjaeristemateriaali ja lietemassa pyrittiin poistamaan maanäytteiden ylimmästä pintakerroksesta ennen näytteiden ottoa.

Taulukko 3. Eri pohjamateriaaleilla varastoidun kemiallisesti hapetetun lietteen alla olleiden maakerrosten $\mathrm{NH}_{4}{ }^{+}-$ ja $\mathrm{NO}_{3}^{-}$-typen profiilit toukokuussa patterien purkamispäivänä.

\begin{tabular}{|c|c|c|c|c|c|c|c|c|c|c|c|c|}
\hline \multicolumn{12}{|c|}{ KOLME POHJAMATERIAALIA S AMALLA LOHKOLLA (HHt, Pohjois-Pohjanmaa) } & \\
\hline \multicolumn{13}{|c|}{ Maakerrosten $\mathrm{NH}_{4}{ }^{+}$ja $\mathrm{NO}_{3}{ }^{-}$-typpi patterin purkamisessa toukokuussa } \\
\hline & \multicolumn{4}{|c|}{ TURVEPOHJA } & \multicolumn{4}{|c|}{ OLKIPOHJA ${ }^{(1)}$} & \multicolumn{4}{|c|}{ PALJASPOHJAINEN } \\
\hline & 2012 & & 2013 & & 2012 & & 2013 & & 2012 & & 2013 & \\
\hline & $(\mathrm{mg} / \mathrm{litra}$ & & $(\mathrm{mg} / \mathrm{kg})$ & & $(\mathrm{mg} / \mathrm{litra}$ & & $(\mathrm{mg} / \mathrm{kg})$ & & $(\mathrm{mg} / \mathrm{litra}$ & & $(\mathbf{m g} / \mathbf{k g})$ & \\
\hline & $\mathrm{NH}_{4}{ }^{+}-\mathrm{N}$ & $\mathrm{NO}_{3}{ }^{-}-\mathrm{N}$ & $\mathrm{NH}_{4}^{+}-\mathrm{N}$ & $\mathrm{NO}_{3}{ }^{-}-\mathrm{N}$ & $\mathrm{NH}_{4}{ }^{+}-\mathrm{N}$ & $\mathrm{NO}_{3}{ }^{-}-\mathrm{N}$ & $\mathrm{NH}_{4}{ }^{+}-\mathrm{N}$ & $\mathrm{NO}_{3}{ }^{-}-\mathrm{N}$ & $\mathrm{NH}_{4}{ }^{+}-\mathrm{N}$ & $\mathrm{NO}_{3}{ }^{-}-\mathrm{N}$ & $\mathrm{NH}_{4}{ }^{+}-\mathrm{N}$ & $\mathrm{NO}_{3}{ }^{-}-\mathrm{N}$ \\
\hline \multicolumn{13}{|l|}{ Patterin kohdalla } \\
\hline kerrokset & 920 & 0 & 185 & 2 & 180 & 0 & 251 & 2 & 430 & 0 & 75 & 3 \\
\hline $10-20$ & 310 & 0 & 117 & 1 & 140 & 0 & 53 & 2 & 120 & 0 & 93 & 2 \\
\hline $20-30$ & 110 & 0 & 82 & 1 & 37 & 0 & 29 & 3 & 96 & 0 & 138 & 2 \\
\hline $30-40$ & 29 & 0 & 51 & 3 & 46 & 0 & 58 & 2 & 21 & 0 & 128 & 2 \\
\hline $40-50$ & 16 & 0 & 17 & 2 & 14 & 0 & 15 & 2 & 4 & 0 & 130 & 2 \\
\hline $50-60$ & 14 & 0 & 11 & 2 & 4 & 0 & 29 & 3 & 7 & 0 & 59 & 3 \\
\hline
\end{tabular}

(1) Olkipohja, molempina vuosina oli pitkää olkea, v. 2013 myös silppua (ei tässä mukana)

Puhdistamolietteen peltohehtaaria kohti lasketussa typpikuormituksessa oli eroja patterien pohjaratkaisujen välillä, myös eri vaihtoehtojen välinen järjestys poikkesi seurantavuosien välillä (Taulukko 4). Olkipohja (pitkä olki) oli molempina vuosina parempi kuin turvepohja. Selkeää syytä turvepohjan heikkouteen ensimmäisenä vuonna ei ole löytynyt. Toisaalta toisena vuonna turvepohja ja olkipohja vaikuttivat toimivilta. Kun patterien levitysalaa kohti laskettua typpikuormaa vertaa mineraalilannoitteissa viljalle yleisesti käytettyyn typpimäärään $90-110 \mathrm{~kg} / \mathrm{ha}$, on patterin vaikutus suhteellisen pieni. 
Taulukko 4. Eri pohjamateriaaleilla varastoidun kemiallisesti hapetetun lietteen varastopatterien kohdalta mitattu $\mathrm{NH}_{4}{ }^{+}$- ja NO${ }_{3}{ }^{-}$-typen pistemäinen kuormitus lannoitevalmisteen käyttölohkon peltohehtaaria kohti laskettuna.

\begin{tabular}{|c|c|c|c|c|c|c|}
\hline & \multicolumn{2}{|l|}{ Turvepohja } & \multicolumn{2}{|l|}{ Olkipohja } & \multicolumn{2}{|l|}{ Paljaspohja } \\
\hline & $\begin{array}{l}2012 \\
\mathrm{NH}_{4}{ }^{+}+\mathrm{NO}_{3}{ }^{-}\end{array}$ & $\begin{array}{l}\mathbf{2 0 1 3}^{(1)} \\
\mathrm{NH}_{4}{ }^{+}+\mathrm{NO}_{3}{ }^{-}\end{array}$ & $\begin{array}{l}2012 \\
\mathrm{NH}_{4}{ }^{+}+\mathrm{NO}_{3}^{-}\end{array}$ & $\begin{array}{l}\mathbf{2 0 1 3}^{(1)} \\
\mathrm{NH}_{4}{ }^{+}+\mathrm{NO}_{3}{ }^{-}\end{array}$ & $\begin{array}{l}2012 \\
\mathrm{NH}_{4}{ }^{+}+\mathrm{NO}_{3}{ }^{-}\end{array}$ & $\begin{array}{l}2013^{(1)} \\
\mathrm{NH}_{4}{ }^{+}+\mathrm{NO}_{3}{ }^{-}\end{array}$ \\
\hline $\operatorname{Kerrossumma~}^{(2)}(\mathrm{kg} / \mathrm{ha})$ & 1399 & 473 & 421 & 446 & 678 & 637 \\
\hline Kerrossumma neliölle $\left(\mathrm{kg} / \mathrm{m}^{2}\right)$ & 0.140 & 0.047 & 0.042 & 0.045 & 0.068 & 0.064 \\
\hline Patterin ala $\left(\mathrm{m}^{2}\right) /$ Lohkon ala (ha) & $114 / 5,13$ & $150 / 5,13$ & $114 / 5,13$ & $150 / 5,13$ & $114 / 5,13$ & $150 / 5,13$ \\
\hline$N$-päästö (kg/patteri) & 15.9 & 7.1 & 4.8 & 6.7 & 7.7 & 9.6 \\
\hline Liukoinen N levitysalaa kohti (kg N/ha) & 3.11 & 1.38 & 0.94 & 1.31 & 1.51 & 1.86 \\
\hline
\end{tabular}

${ }^{(1)}$ Vuoden 2013 pitoisuudet yksikollä mg/kg, summaus ja laskenta lohkotasolle on tehty suoraan tästä yksilöstä, jolloin likimääräinen tulos on yläkanttiin.

${ }^{(2)}$ Maakerrosten typpimäärien yhteenlaskettu summa.

\section{Mädätysjäännöksestä puristuva neste}

Patterisimulaattorista valui nestettä noin 50 litraa 40 vrk kuluessa ja nesteen liukoisen typen pitoisuus oli $2,0 \mathrm{~kg} / \mathrm{t}$ (eli $2,0 \mathrm{~g} / \mathrm{litra})$. Siten kuivatusta mädätysjäännöksestä $(\mathrm{dm} 31,5 \%)$ puristuneen nesteen mukana poistuneen liukoisen typen määrä oli $0,1 \mathrm{~kg} / \mathrm{m}^{2}$ (Taulukko 5). Tämä patterin kohdalla neliömetrille kohdistuva typpipäästö on laskettu taulukossa 5 erikokoisille pattereille ja erikokoisille lohkoille, vaikutuksen suuruuden skaalaamiseksi. Tässä laskennassa oletuksena on että tuotemassan alakerroksiinsa kohdistama paine olisi vakio riippumatta tuotemassan korkeudesta. Todellisuudessa kasvava varastopatterin korkeus voimistaa tuotemassan alakerrosten painetta ja nesteen puristumista. Patterikorkeudet $1,7 \mathrm{~m}$ vastaavat patterisimulaattorin massan korkeutta, mutta matalammat patterikoot taulukossa 5 yliarvioivat vaikutuksen suuruutta koska tuotemassan oma paine olisi todellisuudessa pienempi.

Valumaveden liukoinen typpi oli lähinnä $\mathrm{NH}_{4}{ }^{+}$-typpeä $(86,5 \%), \mathrm{NO}_{3}{ }^{-}$-typpeä oli vain $0,1 \%$. Patterisimulaattorin valumaveden liukoisen fosforin pitoisuus oli hyvin pieni, alle $30 \mathrm{~g} / \mathrm{t}$. Jos neliötä kohti patterisimulaattorista mitatun typpimäärän laskee suoraan hehtaaria kohti, olisi pistemäinen pitoisuus hyvin suuri. Patterin pistemäinen vaikutus on kuitenkin syytä suhteuttaa patterin levitysalaa kohti. Yhtä varastopatteria kohti simulaattorikokeesta mitattu typpipäästö olisi 2-50 kg N/patteri jos patterin peittämä ala olisi $20-500 \mathrm{~m}^{2}$ (Taulukko 5). Kun varastopatteria kohti laskettu typpipäästö jaetaan levitysalaa kohti, on liukoisen typen määrä $2-5 \mathrm{~kg} / \mathrm{ha}$ jos patterin levitysala olisi 1-25 ha.

$\underline{\text { Taulukko 5. Mädätysjäännöksen patterisimulaattorin valumaveden typpi ja skaalaus erikokoisille pattereille. }}$

\begin{tabular}{|c|c|c|c|c|c|c|}
\hline \multicolumn{7}{|c|}{ Patterisimulaattorin ${ }^{(1)}$ valumavesi, massan korkeus $1,7 \mathrm{~m}$} \\
\hline Valumaveden typpipitoisuus ${ }^{(2)}$ & 2.0 & \multicolumn{5}{|l|}{$\mathrm{kg} / \mathrm{tn}(\mathrm{g} / \mathrm{ltr})$} \\
\hline Valumaveden määrä ${ }^{(3)}$ & 50 & \multicolumn{5}{|l|}{$\mathrm{ltr} / \mathrm{m}^{2}$} \\
\hline Valumaveden liukoinen $\mathrm{N}$ neliölle & 0.100 & \multicolumn{5}{|l|}{$\mathrm{kg} / \mathrm{m}^{2}$} \\
\hline \multicolumn{7}{|c|}{ Patterisimulaattorin valumavesipitoisuuden mukainen laskennallinen vaikutus eri kokoluokan tapauksissa ${ }^{(4)}$} \\
\hline \multicolumn{7}{|l|}{ Oletus: Mädätysjäännöksen käyttömäärä $35 \mathrm{~m}^{3} / \mathrm{ha}$} \\
\hline Lohkon ala & & ha & $1.0 \mathrm{ha}$ & 10.0 ha & 10.0 ha & 25.0 ha \\
\hline Patterin ala & & $\mathrm{m}^{2}$ & $20 \mathrm{~m}^{2}$ & $500 \mathrm{~m}^{2}$ & $200 \mathrm{~m}^{2}$ & $500 \mathrm{~m}^{2}$ \\
\hline Patterin korkeus (max) & & $\mathrm{m}$ & $2.0 \mathrm{~m}$ & $1.0 \mathrm{~m}$ & $2.0 \mathrm{~m}$ & $2.5 \mathrm{~m}$ \\
\hline keskimääräinen kork. & & $7 \mathrm{~m}$ & $1.7 \mathrm{~m}$ & $0.7 \mathrm{~m}$ & $1.7 \mathrm{~m}$ & $1.7 \mathrm{~m}$ \\
\hline N-päästö (kg/patteri) & & 5.0 & 2.0 & 50.0 & 20.0 & 50.0 \\
\hline Liukoinen N levitysalaa kohti (kg N/ha) & & 5.00 & 2.00 & 5.00 & 2.00 & 2.00 \\
\hline
\end{tabular}


Patterisimulaattorikoe tehtiin lämpimissä olosuhteissa eli kokonaan sulalla tuotemassalla. Käytännössä talvella perustettavissa varastopattereissa vähintään pintaosat massasta jäätyvät, mikä todennäköisesti vähentää nestevalumaa simulaattorituloksiin verrattuna. Vuonna 2012 Sipoon maanparannuskomposti oli patteria purettaessa suurelta osin jäässä ja maan pintakerroksessa mitattiin äärimmäisen pienet ammoniumtypen pitoisuudet (Sipoo, tuloksia ei näytetty). Mädätysjäännös on yleensä orgaanisten lannoitevalmisteiden tuotetyypeistä kosteimpia. Muiden tuotetyyppien patterisimulaattorikokeita ei ole vielä tehty. Ensimmäinen simulaattoritulos osoittaa että tuotteesta valuvan nesteen kiinniottaminen on todella tärkeää. Sadeveden ja tuotemassan korkeuden vaikutusta massasta puristuvan nesteen määrään tutkitaan edelleen. Ilmeistä on että patterin korkeus ja patterin peittämä pinta-ala on huomioitava patterin pohjakerrosten suunnittelussa.

Valuma sadevedeltä suojatussa patterisimulaattorista keskittyi ensimmäiseen kuukauteen patterin perustamisesta ja jatkui sen jälkeen hitaana toisen kuukauden pysähtyäkseen sitten kokonaan. Pellolla syntyvää ravinnekuormitusta peltopatterin alla voitaisiin merkittävästi vähentää säilyttämällä patteroitavaa orgaanista lannoitevalmistetta esimerkiksi biolaitoksella yhdestä kahteen kuukauteen. Laitoksella tapahtuvassa varastoinnissa lannoitevalmisteen tulisi olla peitettynä ja massasta vapaasti poistuva nestevaluma tulisi keräillä ennen lannoitevalmisteen kuljettamista peltopatteriin. Näin välivarastoitu orgaaninen lannoitevalmiste saavuttaa kullekin tuotteelle ominaisen kuivaainepitoisuuden, jossa se ei enää valuta nestettä. Kun orgaanisesta lannoitevalmisteesta itsestään ei enää valu nestettä, se voitaisiin varsin turvallisesti säilyttää pellolla sadevedeltä suojattuna ilman erityisiä pohjarakenteita. Tarvittava valutusaika ennen peltopatterointia saattaa riippua varastoitavan orgaanisen lannoitevalmisteen ominaisuuksista. Turvamarginaalia voidaan kasvattaa käyttämällä välivarastossa suurempaa kerrospaksuutta kuin mitä se tulisi peltopatterissa olemaan.

\section{Johtopäätökset}

Talvella routaantuneelle maalle perustettavien varastopatterien aiheuttamaa pistekuormaa peltolohkolla voi hallita oikeilla pohjarakenteilla ja varastopaikan viimeistelyllä. Voidaan käyttää nestettä sitovaa mutta myös kantavaa pohjamateriaalia patterin alla. Tarvittaessa voidaan mahdollisesti tehdä massanvaihtoa noin $20 \mathrm{~cm}$ syvyydeltä patterin kohdalla. Varastopatteria ei tule sijoittaa salaojan kohdalle. Orgaanisten lannoitevalmisteiden peltopatteroinnista aiheutuva ympäristönkuormitus on vähäinen, mutta patterin pistemäinen vaikutus on minimoitava. Talvella perustettavien orgaanisten lannoitevalmisteiden peltopatterien ammoniumtyppi on mahdollista ohjata satokasvin käyttöön ilman nitraattipäästöjä, kun patterointi tehdään huolellisesti hyödyntäen nestettä pidättäviä pohjarakenteita.

Käytännöllisiä pohjarakenteiden ratkaisuja (esim. puukuitukerros) ja patterin peittämistä sekä massan korkeuden vaikutusta mahdollisiin valumiin tutkitaan edelleen. Tavoitteena on määritellä riittävän tehokkaat ja toimivat peltovarastoinnin toteutusohjeet sekä selvittää soveliaat pohjamateriaalit. 